\title{
Rainwater composition in northeast Uruguay
}

\author{
M. Zunckel ${ }^{\mathrm{a}, *}$, C. Saizar ${ }^{\mathrm{b}}$, J. Zarauz ${ }^{\mathrm{b}}$ \\ ${ }^{a}$ CSIR Environmentek, P.O. Box 17001, Congella, 4051, South Africa \\ ${ }^{\mathrm{b}}$ Laboratorio Tecnológico del Uruguay, Av Italia 6201, CP 11500, Montevideo, Uruguay
}

Received 21 July 2002; accepted 22 December 2002

\begin{abstract}
The chemical composition of rainfall in northeast Uruguay in 1999 and 2000 and the sources that contribute to the rainwater chemistry are assessed in this study, contributing to a limited knowledge base of rainwater quality in South America. Principal factor analysis and cluster analysis indicate that four main source groups influence the rainfall chemistry over a range of spatial scales. Terrigenous sources (e.g. rock, soil and dust) and agricultural sources (e.g. livestock and crop fertilization) contribute to rainwater chemistry on a local and sub-regional scale. Influx of marine air from the Atlantic Ocean has a regional-scale influence while biomass burning contributes at both a local and subregional scale (e.g. fuel wood, and agroindustries) and through long-range transport (forest fires and land clearing). As may be expected in this area dominated by agriculture, the concentrations of ions that are indicative of industrial emissions, $\mathrm{NO}_{3}^{-}$and $\mathrm{SO}_{4}^{2-}$, are typical of background measurements. The current data are limited, but provide an indication of rain quality and the sources that influence its chemistry in Uruguay. It may be inferred that large-scale biomass burning in the central parts of the continent influence rainwater chemistry on a scale far larger than indicated by the Uruguayan network. Similarly, but to lesser extent, the influx of marine air off the Atlantic Ocean has a greater regional-scale influence than suggested by these data.
\end{abstract}

(C) 2003 Elsevier Science Ltd. All rights reserved.

Keywords: South America; Rainwater chemistry; Factor analysis; Trajectory analysis; Biomass burning

\section{Introduction}

Wet-only rainwater sampling and analysis have been performed by a number of researchers (e.g. Galloway et al., 1982, 1984; Ayres et al., 1995; Galpin and Turner, 1999; Alastuey et al., 2001). This type of work has proved a useful technique for studying the chemical composition of rainwater, provides an understanding of the source types that contribute to rainwater chemistry, and enhances the understanding of local and regional dispersion of pollutants and their potential impacts to ecosystems through deposition processes. For example, the effect of power station emissions on rain quality (Ayres et al., 1995; Marquardt et al., 2001) and the

\footnotetext{
*Corresponding author.

E-mail address: mzunckel@csir.co.za (M. Zunckel).
}

influence of Sahara dust on rain acidity (Löye-Pilot et al., 1986) illustrate contributions from anthropogenic and natural sources to rain chemistry. Galloway et al. (1984) compared the contribution of natural and anthropogenic sources to rain quality and Galpin and Turner (1999) found South African rainwater chemistry to be influenced by a combination of industrial, terrestrial, biomass and marine sources.

Statistical techniques have been used to interpret rain chemistry data in various parts of the world (Crawley and Sievering, 1986; Ezcurra et al., 1988; Bridgman, 1990; Khawaja and Husain, 1990; Galpin and Turner, 1999). Trajectory analysis and regional-scale transport modeling have also been used in various parts of the world to relate observed air pollutants and their deposition to likely source areas over large spatial scales (e.g. Sturman et al., 1997; Tyson and D'Abreton, 1998; Zunckel et al., 2000). 
Andrea et al., (1988, 1990) have studied precipitation chemistry over the central Amazon region in Brazil and Sanhueza et al. (1992) have conducted similar studies over the Savannah region of Venezuela. Little other work however has been done on rainwater quality in Uruguay or elsewhere in South America. An overview study (Grupo de Estudios Ambientals, 1992) highlighted the potential impacts of emissions from fossil fuel-fired power stations in southern Brazil on air and rainwater quality in Uruguay. This study was followed by the initiation of the Uruguay Ambient Air Quality Monitoring Network in 1997, a venture between the Ministerio de Vivienda, Ordenamiento Territorial y Medio Ambiente, (MVOTMA), Laboratorio Tecnológico del Uruguay (LATU) and their South African partner, CSIR Environmentek. The network, monitoring micro-meteorological and air quality parameters and wet-only deposition sampling, was commissioned during 1999.

The aim in this paper is threefold: firstly to gain an initial understanding of rainwater chemistry in the northeast of Uruguay; secondly to identify possible sources that contribute to its chemical composition; and thirdly to establish a baseline record against which possible changes in rainwater chemistry due to changing emission characteristics may be observed. The statistical techniques of factor- and cluster analysis are used to apportion sources that contribute to the chemical composition of rainwater collected in 1999 and 2000. Trajectory analysis is used in a case study to identify the source area associated with black soot observed in rainfall in September 1999.

\section{Study area}

The Uruguay Ambient Air Quality Monitoring Network is located in the northeast of the country (Fig. 1). The weather patterns over the area are strongly influenced by the semi-permanent Pacific and Atlantic anticyclones. The Atlantic anticyclone is responsible for the dominant warm northeasterly winds that occur over the region (NCAR, 1971), while the ridging Pacific anticyclone interrupts the mean flow throughout the year by introducing incursions of cold air from the south by the (Garreaud, 2000). The monitoring network comprises three stations which are roughly aligned north-to-south along the trajectory of the mean northeasterly synoptic-scale flow (Fig. 1). The northernmost station located on the border with Brazil at Aceguá. The second is located at Melo, some $70 \mathrm{~km}$ to the south, with the third station at Treinta y Tres, located a further $130 \mathrm{~km}$ south. Each monitoring site is well exposed and removed from local-scale influences to ensure regional representation from both a meteorological and air quality perspective.

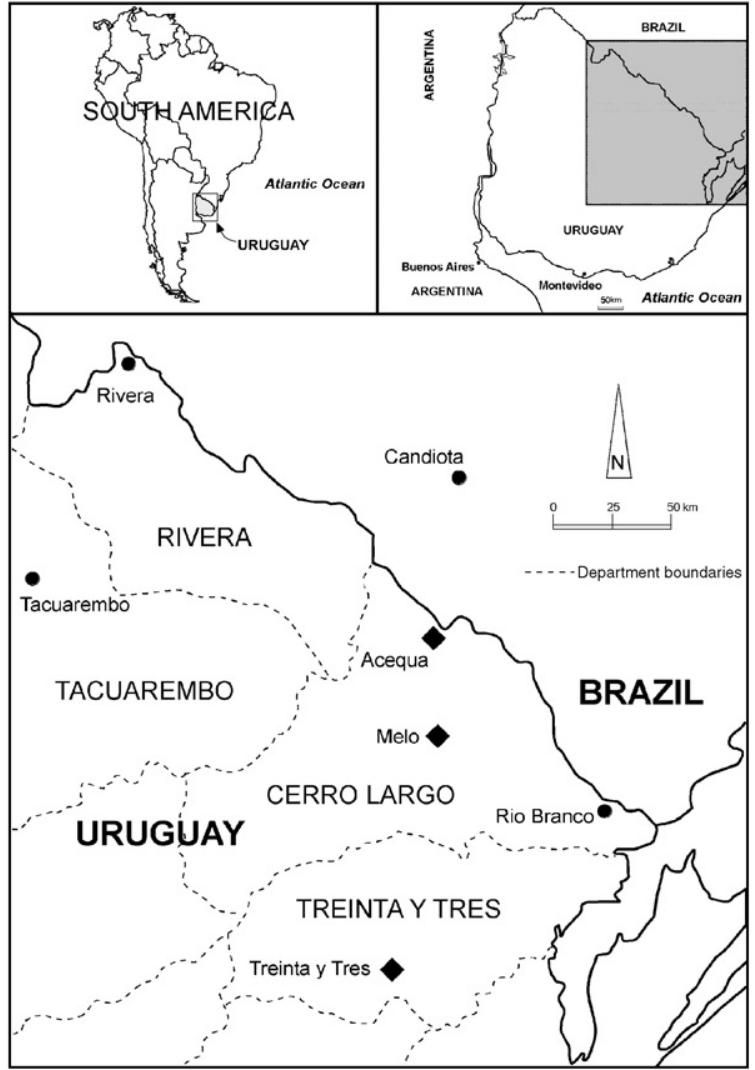

Fig. 1. The position of study area relative to South America and the region, indicating the positions of the three monitoring sites with diamonds.

Land use in the study area is predominantly rangeland and cultivated crops. The population of the region is concentrated in three towns: Aceguá (approximately 1300 inhabitants), Melo (approximately 42000 inhabitants) and Treinta y Tres (approximately 45000 inhabitants) (Grupo de Estudios Ambientals, 1992). The Candiota thermoelectric power station (CTPS), located approximately $50 \mathrm{~km}$ to the northeast of Aceguá in Bagé, Brazil, is the only major sources of industrial air pollution in the region. The study region is bordered by the Atlantic Ocean in the east.

\section{Methodology and data}

\subsection{Sampling and data}

Micros PSM-W/D1-KAA0A automatic wet-and-dry rain samplers are used in a wet-only mode to collect rainwater for later analysis. Sampling is event-specific and the sample is split for field and laboratory analysis. Trained site operators follow a standard rainwater sampling operating protocol based on the ASTM 
International (2002) guidelines for the Collection and Preservation of Atmospheric Wet Deposition, covering all aspects of sample handling and storage. Accordingly, each sample is collected within $2 \mathrm{~h}$ of the end of a rain event. Field analysis of $\mathrm{pH}$ and conductivity is done when the sample is collected. The portion of each sample that is separated for laboratory analysis is stored in polyethylene bottles, pre-cleaned with deionized water, in freezers at each site. Frozen samples were transported in iceboxes to the analytical laboratories in Montevideo with the routine monthly site-maintenance visits. The samples are stored in a freezer in the laboratory until they are prepared for analysis.

The field $\mathrm{pH}$ instruments (Micros PSM-LPH $\mu \mathrm{S}$ AAA0A) are calibrated by the site operators using two

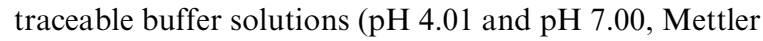
Toledo) each time a sample is collected. Some technical difficulties were experienced with the automatic rain guages at all the stations in 1999. Reliability problems were experienced with the rain sensors which sometimes failed to open the wet sampler lids resulting in samples not being collected. Field $\mathrm{pH}$ and conductivity could not be recorded at times due to power supply problems to the automatic $\mathrm{pH}$ meters. These problems continued at Melo into 2000. Despite this, rainwater was successfully sampled during 1999 and 2000 (70 samples at Aceguá, 41 at Melo and 43 at Treinta y Tres) for ionic analysis.

\subsection{Analytical methodology}

Rainwater samples are analyzed at the Dirección Nacional de Medio Ambiente (DINAMA) laboratory and at LATU on a monthly basis. Each sample is filtered through $0.45 \mu \mathrm{m}$ membrane filter. Ion chromatography is use to determine concentrations of $\mathrm{F}^{-}, \mathrm{Cl}^{-}, \mathrm{NO}_{3}^{-}$, $\mathrm{SO}_{4}^{-}$and $\mathrm{PO}_{4}^{3-}$. Concentrations of acetate and formate are determined using UV-chromatography. $\mathrm{NH}_{4}^{+}$is determined with selective ion electrode. Flame atomic adsorption spectrometry is used to determine $\mathrm{Na}^{+}$, $\mathrm{Ca}^{2+}, \mathrm{Mg}^{2+}$ and $\mathrm{K}^{+}$. Conductivity and $\mathrm{pH}$ measurements in the laboratory are accredited by UKAS following ISO-GUIDE 17025. Acetate and formate will not be preserved for longer than 3 days in samples chilled at $4{ }^{\circ} \mathrm{C}$ (ASTM International, 2002). Therefore, all samples remained frozen until analysis. Prolonged storage times are avoided through the implementation of a monthly analysis programme.

The laboratories did not register for the 1999 World Meteorological Organization/Global Atmospheric Watch (WMO/GAW) Laboratory Intercomparison Program. However, intercomparison samples were provided and these were used for internal quality control. In 2000, the laboratory participated successfully in the the 23rd WMO/GAW Acid Rain Performance Survey (WMO/GAW, 2000). Of the 33 determinations reported (eleven parameters in three samples) 32 values were acceptable, with a single value exceeding the Data Quality Objectives by a factor of 2. Confidence in the determination of all constituents is assured through proper preparation and sample handling at all times, participation in intercomparison programes, the use of Standard Reference materials and Internal Control Samples, and the application of $\mathrm{WMO} / \mathrm{GAW}$ criteria for ion balances.

\section{Results}

The $\mathrm{pH}$ of the rain in the northeast of Uruguay ranges between 7.0 and 4.6 with medians of 5.6 at all three stations in Table 1. The concentrations of the various ions suggest that a range of sources contribute to rain chemistry. These may include sources such as industry, crustal or terrestrial, agricultural, biomass burning and marine. There is a relatively small difference in the mean ionic concentrations at the three sites. However, the differences observed in the range suggest variations in rain chemistry between rain events that are influenced by the dominating source at the time of the event. Factor and cluster analyses are used to assess the various source types and their relative contribution to rain chemistry.

\subsection{Factor analysis}

Principle factor analysis was applied to the 1999 and 2000 data. The data was subjected to a varimax rotation which maximizes the variance to obtain a pattern of loadings on each factor that is diverse as posible, lending itself to easier interpretation. Consecutive factors are uncorrelated or orthogonal to each other. Factor loadings are the correlations of each variable with the factor. Therefore, as the absolute value approaches one, the higher the correlation with the factor. A negative variable loading indicates that it varies in opposite direction to the variables with positive signs.

Three factors have been used in this analysis, giving each variable a loading within each factor. Loadings greater than 0.5 are considered to be significant components of the factor, although in instances variables with smaller loadings are used to assist with the interpretation. The factor loadings and the variance extracted by the factors (eigenvalues) are listed in Table 2. The correlation values between ions and the three principal factors at the $95 \%$ significance level represent $63.2 \%$ and $59.8 \%$ of the total variance of 1999 and 2000 data, respectively.

The first factor explains almost one-third of the total variance of the data for each year $(32.4 \%$ in 1999 and $32.3 \%$ in 2000). This factor suggests both marine and agricultural/livestock sources. Marine sources can be identified by the high negative correlations of $\mathrm{Cl}^{-}, \mathrm{Na}^{+}$ and $\mathrm{Mg}^{2+}$ for both seasons. $\mathrm{Na}^{+}(30.7 \%), \mathrm{Cl}^{-}(55.0 \%)$, 
Table 1

$\mathrm{pH}$ and the minimum, maximum and mean concentrations of the ions in the 1999 and 2000 rain water samplers collected at the three monitoring sites in $\mu \mathrm{eq} 1^{-1}$, with the standard deviation for each ion

\begin{tabular}{|c|c|c|c|c|c|c|c|c|c|c|c|c|}
\hline & $\mathrm{F}^{-}$ & $\mathrm{Cl}^{-}$ & $\mathrm{NO}_{3}^{-}$ & $\mathrm{SO}_{4}^{2-}$ & $\mathrm{PO}_{4}^{3-}$ & Formate & Acetate & $\mathrm{Na}^{+}$ & $\mathrm{NH}_{4}^{+}$ & $\mathrm{K}^{+}$ & $\mathrm{Mg}^{2+}$ & $\mathrm{Ca}^{2+}$ \\
\hline \multicolumn{13}{|c|}{ Aceguà $(N=70, \mathrm{pH}$ median $=5.6)$} \\
\hline Min & $<5$ & $<3$ & $<3$ & $<4$ & $<6$ & $<2$ & $<2$ & $<1$ & $<1.3$ & $<0.6$ & $<0.4$ & $<2.5$ \\
\hline Max & 219.5 & 228.1 & 82.6 & 1088.8 & 8.7 & 160.4 & 27.0 & 1378.4 & 104.8 & 42.7 & 337.3 & 435.1 \\
\hline Mean & 10.8 & 27.4 & 13.9 & 63.5 & 6.1 & 7.6 & 3.4 & 72.4 & 16.1 & 8.4 & 16.1 & 26.7 \\
\hline s.d. & 19.8 & 37.6 & 14.9 & 127.6 & $<6$ & 20.1 & 4.3 & 162.1 & 22.9 & 11.0 & 35.6 & 48.0 \\
\hline \multicolumn{13}{|c|}{ Melo $(N=41, \mathrm{pH}$ median $=5.6)$} \\
\hline Min & $<5$ & 22.0 & 17.1 & 15.0 & $<6$ & $<2$ & $<2$ & 19.1 & $<1.3$ & 1.3 & 4.1 & 4.5 \\
\hline Max & 5.3 & 39.5 & 42.8 & 54.8 & $<6$ & 7.6 & $<2$ & 46.9 & 57.7 & 14.1 & 32.1 & 37.9 \\
\hline Mean & 5.3 & 31.0 & 20.3 & 51.6 & $<6$ & 7.1 & $<2$ & 45.2 & 19.4 & 5.3 & 7.1 & 15.3 \\
\hline s.d. & 8.7 & 38.8 & 17.6 & 164.0 & $<6$ & 17.4 & $<2$ & 134.2 & 26.3 & 6.5 & 10.5 & 22.1 \\
\hline \multicolumn{13}{|c|}{ Treinta y Tres $(N=43, \mathrm{pH}$ median $=5.6)$} \\
\hline Min & $<5$ & 3.4 & $<3$ & $<4$ & $<6$ & $<2$ & $<2$ & $<1$ & $<1.3$ & $<0.6$ & $<0.4$ & $<2.5$ \\
\hline Max & 7.2 & 67.1 & 43.6 & 39.8 & $<6$ & 8.0 & $<2$ & 50.6 & 91.9 & 58.7 & 12.2 & 13.5 \\
\hline Mean & $<5$ & 28.1 & 10.4 & 15.4 & $<6$ & 2.2 & $<2$ & 22.8 & 16.1 & 7.1 & 5.1 & 6.8 \\
\hline s.d. & $<5$ & 36.6 & 11.7 & 14.8 & $<6$ & 2.2 & $<2$ & 29.1 & 24.7 & 9.3 & 6.8 & 6.8 \\
\hline Minimum detection & 5 & 3 & 3 & 4 & 6 & 2 & 2 & 1 & 1.3 & 0.6 & 0.4 & 2.5 \\
\hline
\end{tabular}

Table 2

Factor loadings and the variance extracted by the factors in the 1999 and 2000 rainfall

\begin{tabular}{|c|c|c|c|c|c|c|}
\hline & \multicolumn{3}{|l|}{1999} & \multicolumn{3}{|l|}{2000} \\
\hline & Factor 1 & Factor 2 & Factor 3 & Factor 1 & Factor 2 & Factor 3 \\
\hline $\mathrm{H}^{+}$ & -0.03 & -0.15 & -0.79 & 0.26 & 0.07 & -0.65 \\
\hline $\mathrm{NH}_{4}^{+}$ & 0.76 & 0.09 & 0.12 & 0.80 & -0.10 & 0.38 \\
\hline $\mathrm{Ca}^{2+}$ & -0.07 & 0.00 & 0.67 & 0.04 & 0.78 & -0.07 \\
\hline $\mathrm{Mg}^{2+}$ & -0.62 & 0.30 & 0.40 & -0.64 & 0.51 & 0.20 \\
\hline $\mathrm{Na}^{+}$ & -0.82 & 0.41 & 0.05 & -0.90 & 0.14 & 0.16 \\
\hline $\mathrm{K}^{+}$ & 0.39 & -0.12 & 0.51 & 0.07 & -0.81 & 0.07 \\
\hline $\mathrm{F}^{-}$ & 0.07 & -0.83 & -0.25 & -0.09 & -0.02 & 0.09 \\
\hline $\mathrm{Cl}^{-}$ & -0.76 & 0.47 & 0.04 & -0.84 & -0.02 & 0.19 \\
\hline $\mathrm{NO}_{3}^{-}$ & 0.72 & 0.09 & 0.21 & 0.75 & 0.09 & -0.26 \\
\hline $\mathrm{SO}_{4}^{2-}$ & 0.46 & 0.38 & -0.20 & 0.21 & 0.06 & -0.69 \\
\hline Org. acids & 0.11 & -0.89 & 0.07 & 0.39 & 0.08 & 0.62 \\
\hline Eigenvalue & 3.6 & 2.0 & 1.4 & 3.6 & 1.7 & 1.3 \\
\hline$\%$ total var. & 32.4 & 17.9 & 12.9 & 32.3 & 15.3 & 12.2 \\
\hline$\%$ cumul. var. & 32.4 & 50.3 & 63.2 & 32.3 & 47.6 & 59.8 \\
\hline
\end{tabular}

$\mathrm{SO}_{4}^{2-}(7.7 \%)$, magnesium $\left(\mathrm{Mg}^{2+}\right)(3.6 \%), \mathrm{Ca}^{2+}(1.2 \%)$ and potassium $\left(\mathrm{K}^{+}\right)(1.1 \%)$ are the major ionic species by mass in seawater (Wilson, 1975). The maritime ions are negatively correlated, while agricultural/livestock ions $\left(\mathrm{NO}_{3}^{-}\right.$and $\left.\mathrm{NH}_{4}^{+}\right)$are positively correlated. This means that when the concentration of maritime ions decrease in the sample, the concentration of nitrogen ions increases, suggesting that ammonia and nitrate sources are located inland.
Soils are the major global source of $\mathrm{N}_{2} \mathrm{O}$ accounting for some $65 \%$ of total emissions as a result of microbial processes, while nitrogen fertilizers can be both a direct and indirect source of $\mathrm{N}_{2} \mathrm{O}$ emissions to the atmosphere (Isherwood, 2000). Emissions of $\mathrm{NH}_{3}$ come from anthropogenic sources (livestock, fertilizer applications, sewage, and biomass burning) and natural sources (wild animals, undisturbed soil, vegetation, and the oceans), with manure being the largest single source. About $30 \%$ 
of the nitrogen excreted by farm animals is released to the atmosphere from animal houses, during storage, grazing and application of animal wastes to the soil (Isherwood, 2000). On average, there were about 3 million head of cattle and 5 million head of sheep in the northeastern region of Uruguay, accounting for $28 \%$ of total national stock herd. An estimation of total nitrogen from manure in the region is $250000 \mathrm{ta}^{-1}$, of which about $10 \%$ is readily available as ammonium.

Almost $90 \%$ of the region is used for grazing, of which about $7.5 \%$ is fertilized. Winter fodder crops (oat and ryegrass) are seeded in March-April with a binary fertilizer (N-P), and refertilized with urea in JulyAugust. The seedtime for conventional pastures is from late February to early May, along with fertilizer application (P, N-P or NPK according to soil conditions). Rice and forestry account for $2.3 \%$ and $0.5 \%$ of the total region area, respectively. Recommended practices for rice fertilization are $\mathrm{N}-\mathrm{P}$ application in October-November and urea refertilization in November-December. Approximately $4000 \mathrm{t} \mathrm{a}^{-1}$ of nitrogen is applied on grasslands and rice crops in the northeastern region of Uruguay.

The second factor explains $17.9 \%$ of the total variance observed in 1999 , and $15.3 \%$ of the total variance in 2000 (Table 2). In 1999, Factor 2 shows some correlation with the marine ionic group $\left(\mathrm{Na}^{+} 0.41, \mathrm{Cl}^{-} 0.47\right.$, $\left.\mathrm{Mg}^{2+} 0.30\right)$, but the correlation is much stronger with organic acids and fluoride $(-0.89$ and -0.83 , respectively). Similarly, the opposite sign of the two groups suggest an inland source of organic acids and flouride (e.g. regional forest fires). Potassium, which is a good tracer for wood burning, varies in the same way as organic acids, but has a low loading $(-0.12)$. There is no immediate explanation for this, other than to suggest it is possibly related to the different characteristics of the long-range atmospheric transport of the organic acids (in gas phase) and potassium (mainly associated with particles).

Biomass burning is regarded as the main source of organic acids in rainwater (Glasius et al., 2000). Fuel wood and biomass burning account for about $17 \%$ (approximately $440 \mathrm{kTpe}$ ) of total energy consumption in Uruguay. Recent data for the four northeastern Departments shows that $69 \%$ of the 64300 homes use fuel wood for space heating, $22 \%$ use electricity and $6 \%$ use butane (INE-Instituto Nacional de Estadísticas, 1996). Only $14 \%$ use wood for cooking. Biomass is also burned to clear land for planting, and some agroindustrial wastes (i.e. sawmill residues, rice husks, logging and slash debris) are burned. The northeastern region generates about 180000 tons of rice husks annually, most of which are dumped in landfills where they are burned and smoldered continuously.

The only possible industrial source of fluoride in the region is the CTPS, located approximately $80 \mathrm{~km}$ north of Aceguá (Fig. 1). The fluoride content of coal burned in CTPS is $169 \pm 8$ and $83.5 \pm 2.8 \mathrm{mg} \mathrm{kg}^{-1}$ in the fly ash (Martins and Zanella, 1990). The estimated fly ash emission from CTPS of 88 tons $\mathrm{day}^{-1}$ equates to $7.3 \mathrm{~kg}$ $\mathrm{Fday}^{-1}$. This explains the high levels of fluoride found in pastures located in a radius of $<10 \mathrm{~km}$ from the CTPS (Martins and Zanella, 1990). However, the fluoride content in rainwater samples collected at the CTPS ranged between 0.05 and $0.20 \mathrm{mgl}^{-1}$. By contrast, $\mathrm{F}^{-}$concentrations from the Uruguay network all exceed the upper range at CTPS, with the highest concentration of $1.45 \mathrm{mgl}^{-1}$. If the CTPS were the major source of fluoride observed in the Uruguayan rainwater samples, the highest concentrations would be expected at Aceguá, the closest station to the CTPS, with a clear association with $\mathrm{SO}_{4}^{2-}$. Neither of these assumptions is true, implying other sources contribute to fluoride observed in the Uruguayan rainwater.

Fluoride-containing rocks are considered scarce in Uruguay (Bossi, 1978). Phosphate rocks used in the fertilizer industry contain $2-4 \%$ fluoride, part of which remains in the phosphorous fertilizer. Fluoride in fertilizers can leach into soil. Fertilizer runoff has been considered a source of fluoride contamination in watersheds (ATSDR, 1993). About 290000 tons of phosphate fertilizers are applied annually in Uruguay, but the fluoride content is unknown.

The fluoride correlation with the organic acids appears to be significant only in the 1999 rainfall. This correlation suggests that there may be a link between the trans-national uncontrolled forest fire episodes and the fluoride content of rainwater. The chemical composition of particulate matter from wood combustion shows that this is not a significant source of fluoride. However, during times of drought, the convection generated by the fire's heat may carry dust aloft from the denuded and broken soil surface. Fluoride that may have leached into the soil from previously applied phosphate fertilizers will be entrained in this way. It is hypothesized that longrange transport of soil dust may be the source of fluoride observed in Uruguayan rainfall.

The primary source of the observed $\mathrm{Ca}^{2+}$ and $\mathrm{Mg}^{2+}$ and $\mathrm{K}^{+}$is likely to be of crustal origin from soil and road dust. The opposition of $\mathrm{Ca}^{2+}$ and $\mathrm{Mg}^{2+}$ with $\mathrm{K}^{+}$ may be explained by assuming two different sources: soil and unpaved road dust. Soil compositions have higher mean bulk porcentages of $\mathrm{K}^{+}$than $\mathrm{Ca}^{2+}$ and $\mathrm{Mg}^{2+}$ than $\mathrm{K}^{+}$(Crawley and Sievering, 1986). In general, the soil and crustal profiles are similar, except for the depletion of soluble elements such as calcium, magnesium, and sodium (US EPA, 1999). There are more than $1925 \mathrm{~km}$ of public roadways in the northeastern region (INE-Instituto Nacional de Estadísticas, 2000), including gravel roads and unpaved private roads that are continually disturbed. Agricultural activities such as ploughing may also be considered as sources of crustal 
components. Potassium occurs in coarse particles in soil, but fine particles of potassium result from the combustion of wood. Relatively high levels of potassium may result from agricultural activities (i.e. summer crops or grassland preparation) or fuel wood combustion during winter months.

The third factor accounts for $12.9 \%$ and $12.2 \%$ of the total variance in 1999 and 2000, respectively (Table 2). In 1999, the positive correlation of $\mathrm{Ca}^{2+}$ and $\mathrm{K}^{+}$(and $\mathrm{Mg}^{2+}$, if loadings of 0.4 are included) relate to the crustal ionic group. The high negative correlation of $\mathrm{H}^{+}$ suggests that alkaline compounds containing these cations contribute significantly to the neutralization of precipitation acidity. However, $\mathrm{NH}_{3}$ may play a role in the neutralization process, as it was seen in Factor 1 with the correlation of ammonium with nitrate and also with sulfate (factor loading in the borderline: 0.46).

In 2000, the correlation of $\mathrm{H}^{+}$and $\mathrm{SO}_{4}^{2-}$ suggest acidity from fossil fuel combustion. If loadings of 0.4 are included, organic acids associated with ammonium have a negative correlation with $\mathrm{H}^{+}$and $\mathrm{SO}_{4}^{2-}$, suggesting that organic acids are neutralized by ammonia. This is also present in Factor 1 (organic acids with loading 0.39).

\subsection{Cluster analysis}

The $k$-means method of cluster analysis is applied to the 1999 and 2000 data to associate cluster groups to the potential sources that account for the variations of the chemical composition of the collected rain. The clusters are based on the main sources identified in the Principal Factor Analysis, i.e. Cluster 1: terrigenous (rock and soil dust), Cluster 2: agricultural activity (animal/fertilizer); Cluster 3: acidity (biomass and fossil fuel combustion); and Cluster 4: marine. Cluster 1 is the most numerous (39.4\% of the samples), followed by Cluster $2(25.8 \%)$, Cluster $4(23.5 \%)$ and Cluster $3(11.4 \%)$.
Cluster 1 has influences from mixed sources, but a distinction is the high concentration of sulfate and crustal elements (Table 3 ). The mean sulfate, calcium and potassium contents are the highest of all clusters and magnesium content is the second highest. Other possible sources are marine (about $32 \%$ of $\mathrm{NaCl}$ ) and animal/fertilizer (about 10\% each of $\mathrm{NH}_{4}^{+}$and $\mathrm{NO}_{3}^{-}$).

Cluster 2 has mean ammonium content (29.8\%) (Table 3). The main sources are likely to be from domesticated animals and fertilizers. Relatively high concentrations of nitrate and sulfate (collectively 30.7\%) suggest the neutralization role of these acids by ammonia, which in turn foster the absorption of the gas as ammonium.

Cluster 3 is the acid group, having the highest mean concentration of $\mathrm{H}^{+}$and organic acids (Table 3). The mean sulfate concentration is lower than in Cluster 1 and the mean nitrate concentration is lower than in Cluster 2, but these values do not differ significantly from the highest values, respectively. This suggests that acidity in this group may either result from fossil fuel or biomass combustion. The fluoride content is also the highest among the clusters.

Cluster 4 shows a strong marine influence with the highest concentration of $\mathrm{Na}^{+}$and $\mathrm{Cl}^{-}$(about 30\%), as well as $\mathrm{Mg}(6.3 \%)$ (Table 3$)$. The mean concentrations of all the remaining ions are the lowest of the four clusters or do not differ significantly from the lowest values.

The organic acid group of samples (Cluster 3) is concentrated in the dry winter months (Fig. 2), coinciding with biomass combustion of fuel wood and regional land clearing practices. High ammonium samples in August (Cluster 2) coincide with winter crops fertilization and ammonia absorption favored by organic acids; during spring, fertilization of rice and maize crops, volatilization favored by temperature and the absorption favored by sulfate acidity. The relatively high

Table 3

Ionic composition of each cluster, sorted by concentration as a percentage

\begin{tabular}{|c|c|c|c|c|c|c|c|}
\hline \multicolumn{2}{|c|}{ Cluster 1} & \multicolumn{2}{|c|}{ Cluster 2} & \multicolumn{2}{|c|}{ Cluster 3} & \multicolumn{2}{|c|}{ Cluster 4} \\
\hline $\mathrm{SO}_{4}^{2-}$ & 20.4 & $\mathrm{NH}_{4}^{+}$ & 29.8 & $\mathrm{H}$ & 16.8 & $\mathrm{Cl}^{-}$ & 31.3 \\
\hline $\mathrm{Na}^{+}$ & 16.3 & $\mathrm{NO}_{3}^{-}$ & 15.5 & $\mathrm{SO}_{4}^{2-}$ & 16.1 & $\mathrm{Na}^{+}$ & 27.1 \\
\hline $\mathrm{Cl}^{-}$ & 16.1 & $\mathrm{SO}_{4}^{2-}$ & 15.2 & $\mathrm{NO}_{3}^{-}$ & 13.0 & $\mathrm{SO}_{4}^{2-}$ & 10.7 \\
\hline $\mathrm{NO}_{3}^{-}$ & 10.5 & $\mathrm{Cl}^{-}$ & 10.1 & $\mathrm{~F}^{-}$ & 12.9 & $\mathrm{Mg}^{2+}$ & 6.3 \\
\hline $\mathrm{NH}_{4}^{+}$ & 10.4 & $\mathrm{Na}^{+}$ & 6.3 & Org & 9.1 & $\mathrm{NO}_{3}^{-}$ & 5.7 \\
\hline $\mathrm{Ca}^{2+}$ & 8.5 & $\mathrm{~K}^{+}$ & 5.4 & $\mathrm{NH}_{4}^{+}$ & 8.9 & $\mathrm{Ca}^{2+}$ & 5.3 \\
\hline $\mathrm{K}^{+}$ & 5.5 & $\mathrm{Ca}^{2+}$ & 4.8 & $\mathrm{Cl}^{-}$ & 6.7 & $\mathrm{NH}_{4}^{+}$ & 5.0 \\
\hline $\mathrm{H}^{+}$ & 4.9 & $\mathrm{H}^{+}$ & 4.1 & $\mathrm{Na}^{+}$ & 6.1 & $\mathrm{H}^{+}$ & 4.8 \\
\hline $\mathrm{Mg}^{2+}$ & 4.3 & Org & 3.8 & $\mathrm{Ca}^{2+}$ & 6.1 & $\mathrm{~K}^{+}$ & 2.2 \\
\hline $\mathrm{F}^{-}$ & 1.3 & $\mathrm{Mg}^{2+}$ & 2.5 & $\mathrm{~K}^{+}$ & 2.0 & Org & 0.7 \\
\hline Org & 1.2 & $\mathrm{~F}^{-}$ & 1.8 & $\mathrm{Mg}^{2+}$ & 1.7 & $\mathrm{~F}^{-}$ & 0.5 \\
\hline Total & 99.4 & & 99.3 & & 99.5 & & 99.6 \\
\hline
\end{tabular}




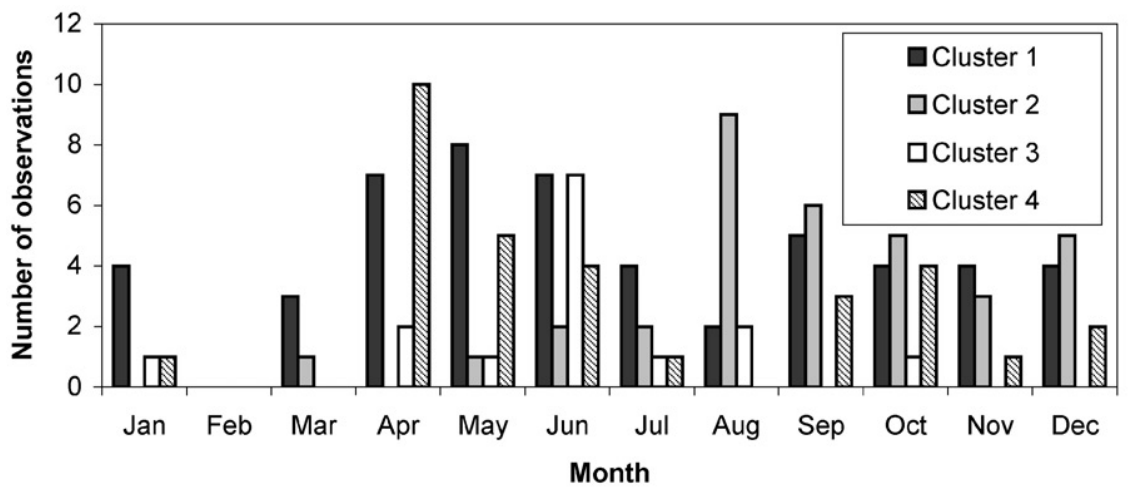

Fig. 2. Monthly variation of the number of samples in each cluster.

crustal elements (Cluster 1) in autumn coincide with extensive ploughing activities. The main influence of maritime air occurs at Treinta y Tres, the southern most station, which will be influenced more strongly and frequently by the ridging Pacific Ocean anticyclone than the stations further north.

\section{Trajectory analysis: case study_black rain event}

On 30 and 31 August 1999, rain observed over the eastern parts of Uruguay was visibly contaminated with black soot. An assessment of the general meteorology forward- and back trajectories and chemical analysis of the rainwater are used to identify the likely origin of the observed soot.

On 30 August a warm front was situated north of Uruguay between $28^{\circ} \mathrm{S}$ and $30^{\circ} \mathrm{S}$, moving southward, while a cold front was situated over Chile, moving north-eastward (Fig. 3). Early on 31 August (03:00), an area of strong convergence occurred between the two fronts over northern and central Uruguay, resulting in convective rain and thunderstorms. By 09:00 the two fronts had occluded and a weak trough extended over much of Uruguay. Initially light to moderate northerly to northeasterly winds prevailed ahead of the warm front, but increased and reached an average of $10.5 \mathrm{~m} \mathrm{~s}^{-1}$ on 30 August. Temperatures were relatively high and reaching $24^{\circ} \mathrm{C}$ at midnight. High particulate counts were recorded at all stations with maximum

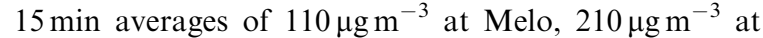
Aceguá and $68 \mathrm{\mu g} \mathrm{m}^{-3}$ at Treinta y Tres. These hot, dry and dusty storm conditions are referred to as Santa Rosa storms which usually occur during August. $\mathrm{SO}_{2}$ concentrations were below 2 ppb throughout the night of 30 August, but an earlier peak of $25 \mathrm{ppb}$ was experienced at Aceguá on the afternoon of 29 August when the light northeasterlies prevailed.

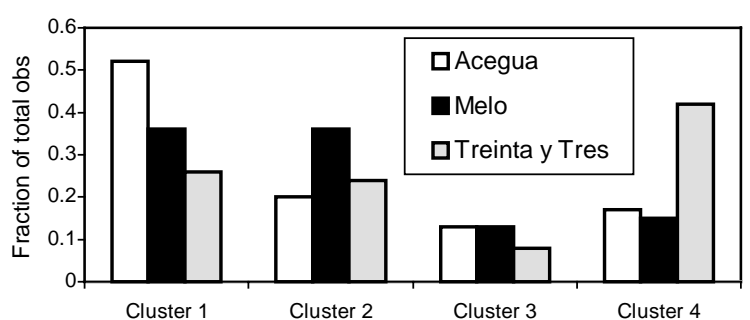

Fig. 3. Number of rain samples in each cluster at the respective stations (top) and the distribution of samples at each station per cluster and month (bottom).

Rain was collected at Melo during the night of the event. The composition of the rain sample deviated from the mean composition prior to the event, and was considerably different than a reference sample (Table 4). High organic acids in the sample, together with the observed black carbon, strongly suggest contamination by biomass burning, but the sulfate and nitrate in the sample suggest industrial contamination.

Fire count data from the advance very high resolution radiometer (AVHRR) instrument on the NOAA 12 satellite shows increased fire activity over the central parts of the continent from 23 to 31 August (Table 5). The AVHRR pixel size varies from $1.1 \mathrm{~km}$ at the center of the image up to about $5 \mathrm{~km}$ at the lateral edges. However, due to the strong thermal energy emitted by the vegetation fires, even a fire front with about $30 \mathrm{~m} \times 0.5 \mathrm{~m}$ will be detected. Thus, a fire pixel may correspond, to a small vegetation fire, or many small fires close to one another, or to a single large fire of $1 \mathrm{~km}^{2}$ (IPE/CPTEC, 1999).

Backward trajectories were run from near Melo at three different heights and ending at 06:00 on 31 August, using the on-line Hybrid Single-Particle Lagrangian Integrated Trajectory Model, employing the omega vertical motion method (Draxler and Hess, 1998), available on the NOAA Air Resources Laboratory 
Table 4

Comparison of selected parameters detected in the Melo rain sample of 30 August, with the maximum and minimum values of previous samples, and with a reference sample

\begin{tabular}{|c|c|c|c|c|}
\hline \multirow[t]{2}{*}{ Parameter } & \multirow{2}{*}{$\begin{array}{l}\text { Value } \\
30 \text { August } 1999\end{array}$} & \multicolumn{3}{|c|}{ From previous samples } \\
\hline & & Maximum & Minumum & Mean \\
\hline $\mathrm{PH}$ & 4.8 & 6.6 & 4.7 & 5.35 \\
\hline Sulfate $\left(\mathrm{mg} \mathrm{l}^{-1}\right)$ & 2.20 & 2.7 & $<0.05$ & 0.87 \\
\hline Nitrate $\left(\mathrm{mgl}^{-1}\right)$ & 2.66 & 3.1 & $<0.05$ & 0.71 \\
\hline \multirow[t]{2}{*}{ Total organic acids $\left(\mathrm{mg}^{-1}\right)$} & 2.85 & 2.85 & $<0.01$ & 0.95 \\
\hline & \multicolumn{2}{|l|}{ Melo sample } & \multicolumn{2}{|c|}{ Reference sample } \\
\hline Total suspended solids & $2 \mathrm{mg} / 1$ & & Not detecte & \\
\hline Color APHA & 40 & & 3 & \\
\hline Turbidity (NTU) & 12.3 & & 0.37 & \\
\hline Organic substance absorbed in UV (Abs) & 0.180 & & 0.006 & \\
\hline
\end{tabular}

Web Site (NOAA, 1999). Each trajectory was found to originate over the western parts of Brazil near $33^{\circ} \mathrm{S} 4$ days earlier. Over a period of 4 days they are shown to move over the active fire region in Brazil and Paraguay before reaching the northeastern parts of Uruguay (Fig. 4 upper panels). It is noteworthy that the height of the three trajectories decreases from their points of origin as they move southward (Fig. 4 bottom panels) over the region of major fire activity, and are at or below $900 \mathrm{hPa}$ by the end of the period. It is highly likely that pyrogenic products are entrained into this southward moving and descending air flow and into the regionalscale rain making process associated with the frontal convergence. It is feasible to suggest that the biomass burning activity in Brazil and Paraguay contributed largely to the contaminated rain that was observed in Uruguay on 30 and 31 August 1999.

Similarly, forward trajectories were run from Candiota to determine whether emissions from the power plant could account for the elevated levels of sulfate and nitrate observed in the same rain sample. Trajectories were initiated at 06:00 and 18:00 on 30 August and
Table 5

Satellite fire pixel counts over South America on 23, 30 and 31 August 1999

\begin{tabular}{lccc}
\hline & 23 August & 30 August & 31 August \\
\hline Argentina & & 468 & 8 \\
Bolivia & & 454 & 54 \\
Brazil & 1633 & 2775 & 3582 \\
Paraguay & 4 & 1151 & 421 \\
Venezuela & & 3 & 3 \\
\hline
\end{tabular}

Source: http://www3.dsa.inpe.br/users/mapas_queimadas/ focos_1999/noaa 12 .

indicate a general flow from the northeast out into the Atlantic Ocean. The exception is the trajectory initiated at 18:00 at $900 \mathrm{hPa}$ which first moves over the eastern parts of Uruguay before exiting the continent (Figs. 5 and 6, upper panels). This trajectory remained at approximately $900 \mathrm{hPa}$, ascending only after it exited the continent (Figs. 5 and 6, lower panels). Ambient $\mathrm{SO}_{2}$ concentrations were low throughout the storm event at all three monitoring sites, even though relatively high
30 August 1999-09:00

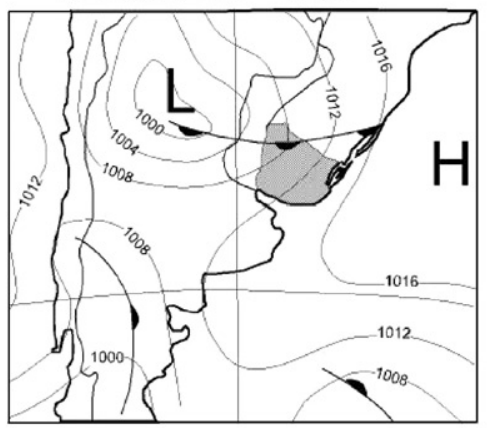

31 August 1999-03:00

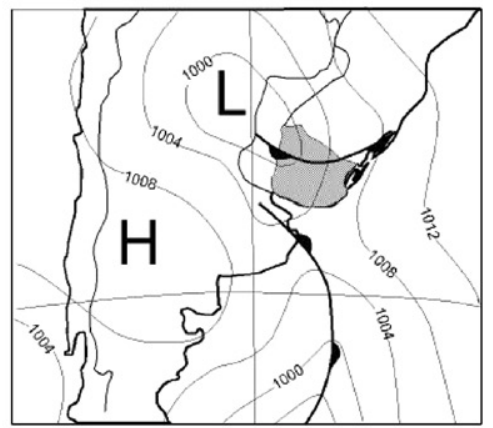

31 August 1999-09:00

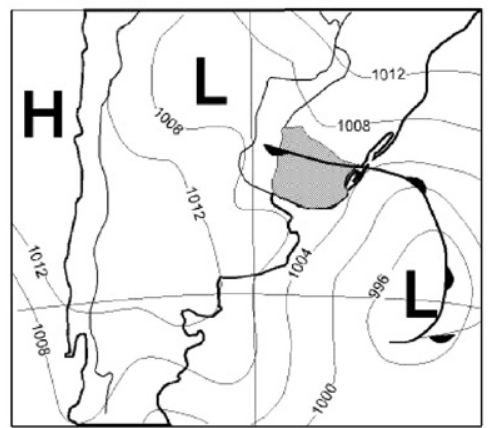

Fig. 4. Surface synoptic charts for the period 09:00 on 30 August 1999 to 09:00 on 31 August 1999. 

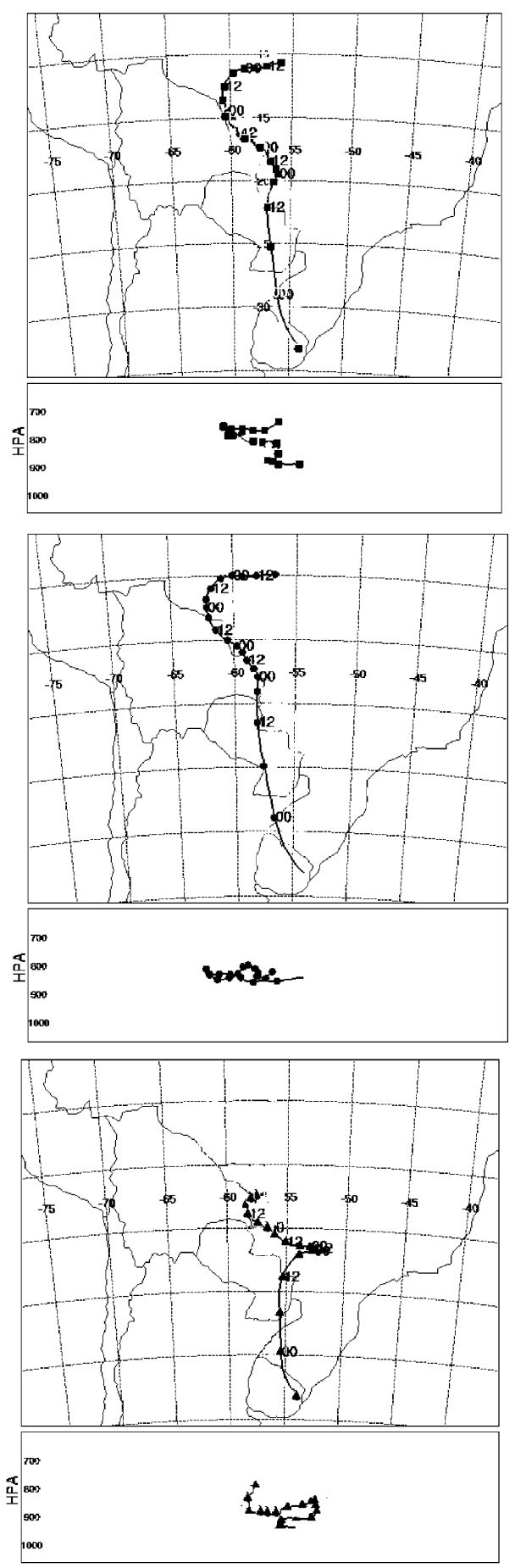

Fig. 5. Backward trajectories from Melo for a 4-day period, ending at 06:00 on 31 August. Midnight (00) and midday (12) are shown along each trajectory path, starting at $750 \mathrm{hPa}$ (top), $800 \mathrm{hPa}$ (center) and $820 \mathrm{hPa}$ (bottom). The corresponding changes of height of each trajectory are shown in the lower frame of each plot. (Source: NOAA, 1999).
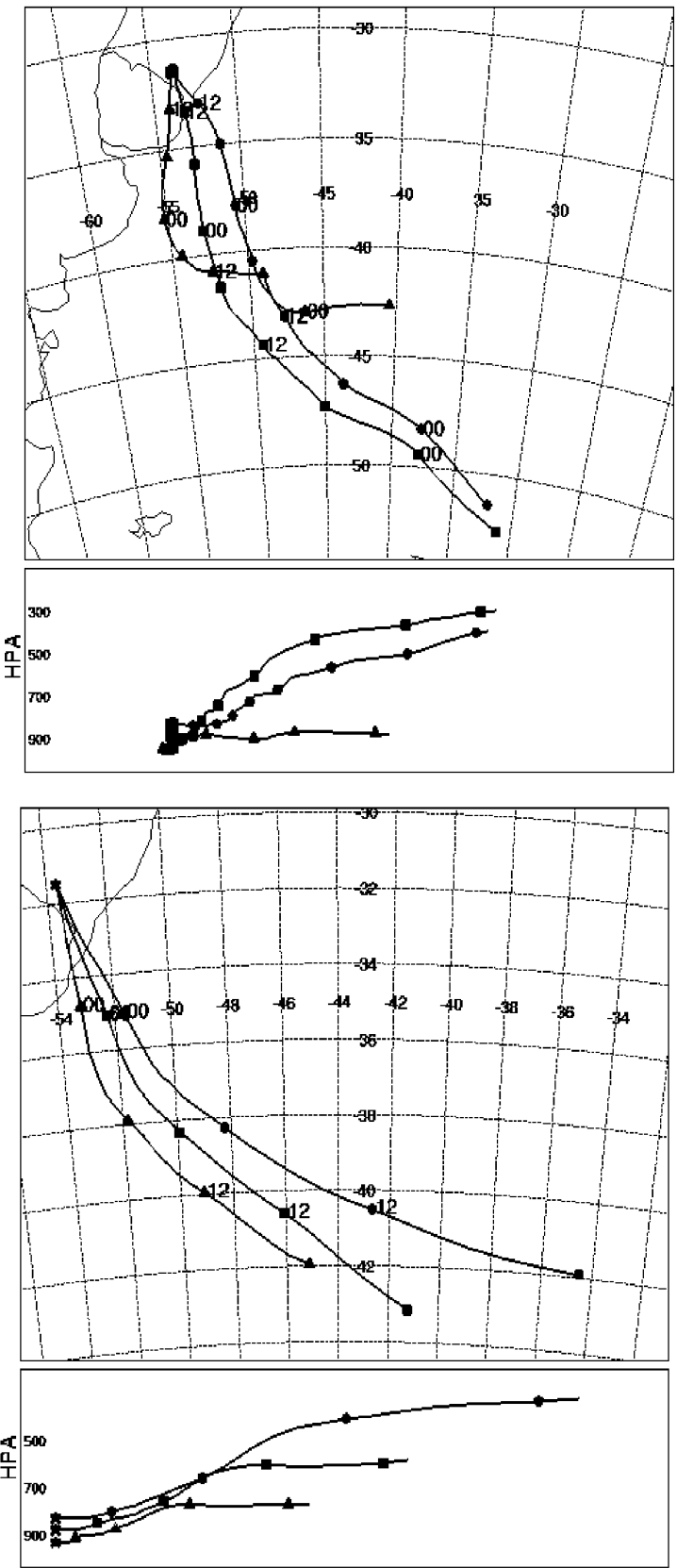

Fig. 6. Forward trajectories from Candiota, starting on 30 August at 06:00 (top) and 18:00 (bottom), respectively. Midnight (00) and midday (12) are shown along each trajectory path. The corresponding changes of height of each trajectory are shown in the lower frame of each plot. (Source: NOAA, 1999). 
sulfate and nitrate concentrations were observed in the Melo rain sample. Biomass emissions are generally low in $\mathrm{SO}_{2}$, suggesting a source other than the biomass fires for the observed sulfate and nitrate concentrations. It is feasible that emissions from Candiota were entrained into the regional-scale rain processes as the air passed low over the region, and were responsible for some of the observed sulfate and nitrate observed in the Melo sample.

It appears that the black rain event observed in the northeast of Uruguay on the night of 30 August 1999 is attributed to large-scale biomass burning in Brazil and Paraguay. Pyrogenic products such as soot, ash, aerosols and gases became entrained into the northerly to northeasterly synoptic-scale flow and into the regional-scale rain process associated with the merging of southward moving warm front and the easterly moving cold front.

\section{Conclusion}

Rainwater collected in Uruguay at Aceguá, Treinta y Tres and Melo 1999 and 2000 is analyzed for a full suite of ions in accordance with WMO/GAW criteria and standards. Principal factor analysis and cluster analysis have been used to develop an understanding of rainwater chemistry in northeast Uruguay and of the contributing sources.

The $\mathrm{pH}$ of rainwater is typical of background sites. Statistical analysis suggests the Uruguayan rain chemistry is influenced by a combination of sources. These include terrigenous sources (rock, soil and dust), agricultural sources (livestock and crop fertilizers), marine sources and biomass burning (fuel wood and forest fires).

A correlation between chloride, sodium and magnesium, suggests a contribution from a marine source to the Uruguayan rainwater chemistry. In turn, a correlation between nitrate and ammonium is attributed mainly to livestock and fertilizer use. Correlations between fluoride and organic acids suggest a contribution from activities such as biomass burning, the use of fuel wood, agroindustries and the use of crop fertilizer. A correlation between calcium and magnesium implies a contribution from crustal sources such as unpaved roads, wind blown dust from bare soils and ploughing. These two ions correlate negatively with potassium, which is a good indicator of biomass burning. Trajectories from active fires in the central parts of South America were shown to pass over northeast Uruguay and to correspond with peaks in pyrogenic indicators in the observed rainfall.

A range of sources influences Uruguayan rainfall over a range of spatial scales. Terrestrial sources, livestock and other agricultural activities and fuel wood combustion contribute on a sub-regional scale, marine products originating over the Atlantic Ocean influence the chemistry on a regional scale. Rainfall chemistry is also influenced by biomass burning in the Amazon region through long-range transport.

This is an initial analysis, based on a limited data set. The conclusions on sources of rainwater constituents are by no means definitive. They do however provide the first insight into the nature of Uruguayan rainwater quality. In the light of proposed expansion of coal-based power generation in the region, it is important that rainwater monitoring is continued. These initial data provide an ideal baseline against which changes in rainwater quality as a result of local and regional land use changes, may be monitored.

\section{Acknowledgements}

The Direccion Nacional de Medio Ambiente, MVOTMA, supported this study. We would like to express our gratitude to MVOTMA for their role in making this work possible. The analytical personnel at MVOTMA and LATU are acknowledged for their contribution to this work through the rainwater analysis. Arjoon Singh at CSIR Environmentek is thanked for his work on the figures.

\section{References}

Alastuey, A., Querol, X., Chaves, A., Lopez-Soler, A., Ruiz, C.R., 2001. Wet-only sequential deposition in a rural area in north-eastern Spain. Tellus 53B, 40-52.

Andrea, M.O., Talbot, R.W., Andrea, T.W., Harriss, R.C., 1988. Formic and acetic acids over the central Amazon region, Brazil 1 dry season. Journal of Geophysical Research 93, 1616-1624.

Andrea, M.O., Talbot, R.W., Berresheim, K.M., Beecher, K.M., Li, S.M., 1990. Precipitation chemistry over central Amazonia. Journal of Geophysical Research 95D, 16987-16999.

ASTM International, 2002. D5012-01 standard guide for preparation of material used for the collection and preservation of atmospheric wet deposition, http://www. astm.org/DATABASE.CART/PAGES/D5012.htm.

ATSDR, 1993. Agency for Toxic Substances and Disease Registry, US Public Health Service, US Department of Health and Human Services, Atlanta, GA, http:// www.atsdr.cdc.gov/tfacts11.pdf.

Ayres, G.P., Gillett, R.W., Selleck, P.W., Bentley, S.T., 1995. Rainwater composition and acid deposition in the vicinity of the fossil fuel-fired power plants in southern Australia. Water, Air and Soil Pollution 85, 2313-2318.

Bossi, J., 1978. Recursos Minerales del Uruguay. In: Aljanati, D. (Ed.), Montevideo.

Bridgman, H., 1990. Evaluating rainwater contamination and sources in Southeast Australia using factor analysis. Atmospheric Environment 26A (13), 2401-2412. 
Crawley, J., Sievering, H., 1986. Factor analysis of the MAP3S/ RAINE precipitation chemistry network: 1976-1980. Atmospheric Environment 20 (5), 1001-1013.

Draxler, R.R., Hess, G.D., 1998. An overview of the HYSPLIT-4 modelling system for trajectories, dispersion and deposition. Australian Meteorological Magazine 47, 295-308.

Ezcurra, A., Casado, H., Lacaux, J.P., García, C., 1988. Relationships between meteorological situations and acid rain in Spanish Basque Country. Atmospheric Environment 22 (12), 2779-2786.

Galloway, J.N., Likens, G.E., Kneen, W.C., Miller, J.M., 1982. The composition of precipitation in remote areas of the world. Journal of Geophysical Research 87 (11), 8771-8786.

Galloway, J.N., Likens, G.E., Hawley, M.E., 1984. Acid precipitation: natural versus anthropogenic components. Science 226, 829-831.

Galpin, J.S., Turner, C.R., 1999. Trends in composition of rain quality data from the South African interior. South African Journal of Science 95, 225-228.

Garreaud, R.D., 2000. Cold air incursions over subtropical South America: mean structure and dynamics. Monthly Weather Review 128, 2544-2559.

Glasius, M., Wessel, S., Christensen, C.S., Jacobsen, J.K., Jørgensen, H.E., Klitgaard, K.C., Petersen, L., Rassmussen, J.K., Hansen, T.S., Lohse, C., Boaretto, E., Heinemeier, J., 2000. Sources of formic acid studies by carbon isotopic analysis and air mass characterization. Atmospheric Environment 34 (15), 2471-2479.

Grupo de Estudios Ambientals, 1992. Lluvia Acida-Candiota, coordinator D. Tor, Ediciones, Montevideo.

INE-Instituto Nacional de Estadísticas, 1996. Serie Colecciones-VII Censo de Población, III de Hogares y V de Viviendas-Año 1996, http://www.ine.gub.uy/biblioteca/ publicaciones.htm.

INE-Instituto Nacional de Estadísticas, 2000. Anuario Estadístico 2000, http://www.ine.gub.uy/biblioteca/anuario2000/ marcos_anuario_2000.htm.

IPE/CPTEC, 1999. Queimadas no Brasil-Vegetation fires in Brazil, Grupo Queimadas, http://atiaia.cptec.inpe.br/products/queimadas/queimap.html.

Isherwood, K.F., 2000. Mineral Fertilizer Use and the Environment, IFA/UNEP (Rev. version 03/2000).
Khawaja, H.A., Husain, L., 1990. Chemical characterization of acid precipitation in Albany, New York. Atmospheric Environment 24A, 1869-1882.

Löye-Pilot, M.D., Martin, J.M., Davis, T.D., 1986. Influence of Saharan dust on the rain acidity and atmospheric input on the Mediterranean. Nature 321, 427-428.

Marquardt, W., Brüggemann, E., Renate, A., Herrmann, H., Möller, D., 2001. Trends of pollution in rain over East Germany caused by changing emissions. Tellus B 53 (5), 529-545.

Martins, A.F., Zanella, R., 1990. Estudo analítico-ambiental na regiao carbonergética de Candiota, Bagé (RS). Ciéncia e Cultura 42 (3/4), 264-270 Marco/April.

NCAR, 1971. National Centre for Atmospheric Research, Climate of the upper air: Southern Hemisphere, Vol. 3Vector mean geostrophic winds, NCAR Technical Notes, NCAR-TN/STR-58.

NOAA, 1999. Air Resources Laboratory, Real-time Environmental Application and Display System (READY), http: //www.arl.noaa.gov/ready.html.

Sanhueza, E., Arias, M.C., Donoso, L., Graterol, N., Hermoso, M., Martí, I., Romero, J., Rondón, A., Santana, M., 1992. Chemical composition of acid rains in the Venezuelan savannah region. Tellus 44B, 54-62.

Sturman, A.P., Tyson, P.D., D'Abreton, P.C., 1997. A preliminary study of the transport of air from Africa to Australia and New Zealand. Journal of the Royal Society of New Zealand 27 (4), 485-498.

Tyson, P.D., D'Abreton, P.C., 1998. Transport and recirculation of aerosols off Southern Africa-Macroscale plume structure. Atmospheric Environment 32 (9), 1511-1998.

US EPA, 1999. Air quality data for particulate matter. Office of Research and Development, External Review Draft, EPA821-R-99-002.

Wilson, T.R.S., 1975. Salinity and major elements in sea water. In: Riley, J.P., Skirrrow, G. (Eds.), Chemical Oceanography, 2nd Edition. Academic Press, London. UK, pp. $365-413$.

WMO/GAW, 2000. Report on the 23rd WMO/GAW Laboratory Intercomparisons, Atmospheric Sciences Research Centre, University of Albany, http://marble.asrc.cestm.albany.edu/qasac/lab_ic/anal00.

Zunckel, M., Robertson, L., Tyson, P.D., Rodhe, H., 2000. Modelled transport and deposition of sulphur over Southern Africa. Atmospheric Environment 34 (2000), 2797-2808. 